\title{
THE HINDU, THE MUSLIM, AND THE BORDER IN NATIONALIST SOUTH ASIAN CINEMA
}

\author{
Vinay Lal \\ University of California, Los Angeles
}

\begin{abstract}
There is but no question that we can speak about the emergence of the (usually Pakistani or Muslim) 'terrorist' figure in many Bollywood films, and likewise there is the indisputable fact of the rise of Hindu nationalism in the political and public sphere. Indian cinema, however, may also be viewed in the backdrop of political developments in Pakistan, where the project of Islamicization can be dated to least the late 1970s and where the turn to a Wahhabi-inspired version of Islam is unmistakable. I argue that the recent history of Pakistan must be seen as instigated by a disavowal of the country's Indic self, and similarly I suggest that scholarly and popular studies of the 'representation' of the Muslim in "Bollywood" rather too easily assume that such a figure is always the product of caricature and stereotyping. But the border between Pakistan and India, between the self and the other, and the Hindu and the Muslim is rather more porous than we have imagined, and I close with hints at what it means to both retain and subvert the border.
\end{abstract}

Keywords: Border, Communalism, Indian cinema, Nationalism, Pakistan, Partition, Veer-Zaara

\section{RESUMEN}

Así como el personaje del 'terrorista' (generalmente musulmán o paquistaní) está presente en muchos filmes de Bollywood, el nacionalismo hindú está tomando la iniciativa en la esfera política del país. Sin embargo el cine indio también puede hacerse eco de acontecimientos ocurridos en Paquistán, donde desde los años Setenta se ha manifestado un proceso de islamización de la sociedad, con una indudable impronta wahabí. Estimo que la historia reciente de Paquistán intenta deshacerse de su legado hindostánico, a la vez que señalo que los estudios sobre el musulmán en "Bollywood" pecan de simplificarlo como un arquetipo, si no una caricatura. Pero la frontera entre India y Paquistán, entre Yo y el Otro, es decir, entre musulmanes e hindúes es más porosa de lo que cabe imaginar, lo que me lleva a concluir en las opciones de mantenerla y subvertirla.

Palabras clave: Border, Comunalismo, Cine indio, Nacionalismo, Paquistán, Partición, Veer-Zaara. 
Most film scholars in India, as well as urban, sophisticated film viewers, take it as nearly axiomatic that mainstream Indian cinema has since around the late 1980s and early 1990s, when Hindu nationalism was exercising considerable force in Indian politics, become nationalistic and even jingoistic. There certainly appears to have been a proliferation of films which take as their subject the turmoil in the north Indian state of Kashmir: not only is this disputed territory, to which Pakistan also lays claim, but it has been the site of secessionist tendencies and a sustained resistance movement against the Indian state. Much like the Palestinian Intifada, the resistance movement in Kashmir has gone through several iterations and phases, but the underlying roots of the conflict seem far from being resolved. The official Indian view has long been that the struggle over Kashmir is driven less by the aspiration for an autonomous homeland and much more so by the nefarious activities of Pakistan and its various agencies, in particular the military and the country's premier intelligence gathering organization, the Inter-Services Intelligence (more popularly known by its acronym, ISI). Pakistan is held by India to be a principal sponsor of what is called cross-border terrorism, and nearly everyone agrees, whatever one's views about the aspirations for Kashmiri independence, that the problems in Kashmir have been compounded with the advent of Islamic terrorism. Consequently, mainstream Hindi-language cinema may be viewed as reflecting some of these political developments. A spate of recent popular films has also taken as their subject the presence of the terrorist within Indian society; others have conjured up scenarios of India being held hostage to the design of Islamic terrorists in the hunt for a nuclear bomb; and yet others have attempted to place India within the orbit of geopolitical Islam. We should certainly recall, if the last scenario seems improbable, or if the battles presently raging in many Muslim societies in the Arab world seem to be at a considerable distance from the vastly different contours that Islam has taken in South Asia over the course of a millennium, that Osama bin Laden's various manifestoes calling for a worldwide jihad against infidels enumerate Kashmir alongside Palestine, Saudi Arabia, Chechnya, and Afghanistan as one of the sites where Islam needs to be freed from the shackles of oppression. ${ }^{1}$

In all these respects, then, it can scarcely be doubted that popular Indian cinema for something like three decades has displayed a growing propensity and capacity for engaging with the idea of conflict between India and Pakistan, largely over Kashmir but also, in various often unstated ways, over the interpretation of Islam and the social mores of two societies that in the aftermath of Partition and

${ }^{1}$ Kashmir is listed in Osama bin Laden's “Declaration of Jihad," 23 August 1996, among those places where Muslims have been massacred. Kashmir was mentioned again by bin Laden as a place that required liberation from the infidel in a wide-ranging interview that he gave on October $21^{\text {th }}, 2001$, to the al-Jazeera reporter, Taysir Alluni, at an undisclosed location near Kabul. On 26 December 2001, in what would become his lengthiest celebration of the nineteen "students" who had shaken America to the core, bin Laden described the events of September $11^{\text {th }}$ as "merely a response to the continuous injustice inflicted upon our sons in Palestine, Iraq, Somalia, southern Sudan, and other places, like Kashmir." 
the creation of the new nation-state of Pakistan began to drift apart in significant ways. It must not be supposed, however, that it is only on account of the insurgency in Kashmir in 1989, following the disputed election of 1987, that Indian filmmakers became sensitized to the simmering conflict in that state, or that they have been only capitalizing on, as it were, the anxiety over Islamic terrorism that has been seen the world over. One could easily point to several other considerations that have facilitated Indian filmmakers' relatively new-found engagement with the question of Kashmir, the political contours of Islam, or the difficulties in which Indian Muslims have found themselves in a pluralistic society as representatives of a faith over which hangs the ever-deepening shadows of suspicion. I have briefly adverted already to the rise of Hindu nationalism in the 1980s, an emergence all the more striking in view of the fact that Hindu nationalists, in the wake of the assassination of Mohandas Gandhi on $30^{\text {th }}$ January 1948, were cast into the wilderness. Just days after Gandhi's murder, the Rashtriya Swayamsevak Sangh (RSS), the same organization of which India's present Prime Minister is a card-carrying member, was banned as it had engaged in violent activities and exhorted people to violence. (Guha 110-111). The conventional account speaks of the Nehruvian consensus, built around the values of a secular Republic and socialized state planning, as regnant in Indian society and politics until around a decade after the death of Jawaharlal Nehru in 1964, and it is unquestionably true that Hindu parties and organizations were shut out of formal politics until around the mid-1970s. The Bharatiya Janata Party, built in part from the remnants of the Hindu nationalist party Jana Sangh, was founded in 1980; and few people will remember that the BJP, which now commands an absolute majority of 282 in the 545-seat Lok Sabha, (the lower house of the Indian Parliament), won only two seats in the general election of 1984. That is one, rather unambiguous, indication of how far Hindu nationalism has traveled in the last three decades. But even burgeoning Hindu nationalism in a transparently political register does not furnish the entire story. Many of those who played a critical role in the expansion of popular Hindi-language cinema in the aftermath of independence — directors and screen writers K.A. Abbas, Zia Sarhadi, Mehboob Khan, and Abrar Alvi, lyricists and poets Sahir Ludhianvi, Majrooh Sultanpuri, Kaifi Azmi, and Jan Nisar Akhtar, the music director Naushad, to mention just a few names - were Muslims, and even those who were not had grown up, matured, and prospered in a social milieu where Hinduism and Islam inhabited the same space. By the mid-1970s many of the veteran Muslim personalities in the film industry had retired or passed away; the element of Urdu in conversational Hindustani had greatly diminished as well, and by around 1990 the generation that became prominent in various aspects of the film industry had no awareness as such of the Indo-Islamic synthesis that had been so characteristic an aspect of the culture of north India. The circumstances were ripe for the confluence of Hindi, Hindu, and Hindustan. 
If Partition was an immensely traumatic moment, and there is little reason to doubt that, it becomes a question of paramount importance to ask why there were no cinematic treatments of this subject until twenty-five years after the vivisection of India or what in Pakistan is called the attainment of azaadi (freedom). Popular Hindi films were scrupulous in their avoidance of the very mention of Pakistan, and it is striking that the film Upkar (1967), which is set against the 1965 India-Pakistan war, was able to become a paean to patriotism without so much as mentioning Pakistan. Its story of two brothers, the younger of whom acquires an education overseas at his older brother's expense and then returns home to demand his share of the family property, echoed the story of India and the demand of the adherents of Islam, the younger faith, that there be a division of the country. If Pakistan was never mentioned, should one suppose that its very existence was thus never recognized, or that this signified the inability of Indians to recognize the finality of the Partition? Were the wounds of the psychic trauma so deep as to prevent an interrogation of many cherished assumptions about the uniquely syncretic nature of the Indian past or of the willingness of Muslims to accept their place as the younger siblings within a Hindu dispensation? I have elsewhere suggested, however, a contrary view, one that insists on the Hindi film's fundamental and insistent engagement with the Partition throughout the 1950s and 1960s, except that this was always effected through an act of displacement (Lal 2010: 10-11; Lal 2013: passim). The prevalence of what might be called the 'lost and found' motif in popular films, or the frequently encountered plot of siblings - often two brothers, sometimes two sisters or three brothers - who veer off in different directions, only to reconcile or, where they were separated in infancy or early adolescence and thus unaware of the presence of each other, unite towards the end of the film cannot satisfactorily be understood on any other grounds. ${ }^{2}$ The catastrophe that strikes the rich merchant in the film Waqt (Time, 1965), directed

2 The most iconic representation of the two brothers whose paths diverge, but who are attached to their mother's bosom, and more than anything else vie for her love and affection, is the film Deewaar (The Wall, 1975), directed by Yash Chopra (for an interpretation of this pivotal film, see Lal 2010). A skeptic might well argue that the Abel and Cain story is universal, or that variants of this story are to be found across cultures; but the sheer ubiquitousness of this motif in popular Indian culture gives it a different standing, arising as it does both from the marvelously rich world of Puranic literature and the immediacy and gravity of the experience of the partition of India, which left few families in north India untouched. Other popular Hindi-language films in this 'genre' include Ram aur Shyam (1967), Seeta aur Geeta (1972, featuring female twins), and Kishen Kanhaiya (1990). Manmohan Desai's Amar Akbar Anthony (1977) has most often been understood as a plea for religious tolerance: three brothers are separated in childhood, and one is raised in a Hindu household, another by a Muslim tailor, and the third by a Catholic priest. But Yaadon ki Baarat (Procession of Memories, directed by Nasir Hussain), which preceded Desai's film by four years and also revolves around three brothers separated by dint of circumstances in childhood and eventually brought together by a song they often sung in unison as children, suggests why it is also possible to read these allegories of national integration as commentaries on the trauma of Partition. 
by the Lahore-born Yash Chopra, ${ }^{3}$ is not only what the Gods have in store for those who are consumed by hubris: the earthquake that shatters his home, sets the town ablaze, scatters his family, and separates the three brothers bears unmistakably all the signs of the tragedy that became the Partition. It is perhaps not accidental that the Hindi cinema's first and to this day the most moving full-length engagement with the Partition motif, M.S. Sathyu's Garam Hawa (Hot Winds), came in 1973, shortly after the 1971 war between Pakistan and India that, leading as it did to the separation of East Pakistan and West Pakistan and the birth of Bangladesh, dealt the most decisive blow to the two-nation theory and to the idea that identity in India was determined predominantly and sometimes exclusively by religious affiliation.

The Hindu nationalist turn in popular cinema may also have owed something to developments in Pakistan, and more specifically to the fact that South Asian Islam was beginning to fall hostage to the notion that it was an inauthentic and feebler version of the Islam of Muhammad's homeland. Scholars and activists who have rightly deplored the tendency in India to doubt the Indian Muslim's loyalty to the motherland, which is of course greatly aggravated not just at war-time but in the course of events such as India-Pakistan cricket matches, are however oblivious to the fact that South Asian Muslims have over the decades been slowly weaned from their distinct socio-cultural and religious practices. ${ }^{4}$ The proximity of Hinduism to Muslims in the Indian sub-continent was always discomforting to the orthodox. Colonial ethnographers had documented the presence of hundreds of communities which claimed allegiance to both Islam and Hinduism, refusing to identify themselves as purely Muslims or Hindus: in this respect, the Shias were held by the orthodox to be especially culpable, and the last Shia ruler of Awadh, Wajid Ali Shah, who staged dramas based on Hindu myths at his court and himself played the role of the god Krishna, was pilloried as an illustration of the manner in which Hinduism had made inroads into Islam. Speaking of comparatively contemporary times, there is a considerable body of work on the Islamization of Pakistan that commenced with the military regime of General Muhammad Zia-ul-Haq, who took power in 1977, unabashedly described himself as a "soldier of Islam," and ruled until his death in a plane crash in 1988. The establishment of Sharia benches in Pakistan's High Courts,

\footnotetext{
3 The émigré origins of Yash Chopra, who grew up in Lahore, significantly if not decisively shaped his oeuvre.

${ }^{4}$ The murder in broad daylight of the Sufi singer, Amjad Sabri, on the streets of Karachi two years ago is one of the many ominous portents of the growing intolerance in Pakistan for anything but the Wahhabi version of Islam. Though it has become somewhat fashionable for liberal academics in the West to speak of the 'varieties of Islam', partly in a bid to distance themselves from the ever-increasing din about 'Islamic terrorism', there is little appreciation of the fact that in South Asia there was what may be called a distinct Indo-Islamic cultural synthesis forged over several centuries. Muslims in Pakistan, especially, have been encouraged to believe that the only 'authentic' home of Islam is Saudi Arabia, and that one must be ever watchful that the idolatry of the Hindus which purportedly led to the contamination of Islam - worship at mausoleums of Sufi saints, the faith in pirs (teachers), the presence of Sufi music - does not creep back into the life of the devout Muslim. See Lal 2016.
} 
and the imposition of the Hudood Ordinances, which mandated punishments such as amputation and stoning by death for fornication, adultery, and other like offences, was justified by Zia-ul-Haq with the argument that "Pakistan, which was created in the name of Islam will continue to survive only if it sticks to Islam. That is why I consider the introduction of [an] Islamic system as an essential prerequisite for the country"5 (see Ispahani ch 5; Haqqani 127). Relations between Saudi Arabia and Pakistan had always been good; under Zia-ul-Haq, the two countries were deemed to have a special relationship, and Saudi support for Pakistan grew exponentially and today continues to play a critical role in the shaping of Pakistani society. It is in Zia-ul-Haq's time that Pakistani cinema, which had flourished in the two decades preceding his assumption of power, and had even received a boost with the ban on Indian films that came to be rigorously enforced after the war of 1965, began to flounder and would soon find itself decimated. Movies became stigmatized as un-Islamic, even if Zia-ul-Haq's own family were addicted to Bombay cinema, and many cinema halls were torn down in Pakistan to make way for shopping plazas. One may argue that the destruction of cinema halls was precipitated by many other considerations as well, preeminently the video cassette boom which was followed by the video CD revolution, both of which facilitated the easy viewing of pirated films at a fraction of the cost of a movie ticket. Lahore, the cultural center of Pakistan, is said to have been deeply affected (Rizwan 2005). ${ }^{6}$ One writer has even alleged, though I have not found any confirmation of his claim from any other source, that cinemas were completely shuttered in Islamabad, the capital of Pakistan (Altaf 2013). If that was the case, Islamabad would have shared that dubious distinction with Riyadh of a capital city without any cinema halls. What is much more likely is that clandestine venues developed for screening films: we may have to work with a much more heterogeneous, mobile, and vernacular conception of the cinema hall itself.

Among India's Muslims, similarly, the infusion of Saudi money has strengthened the hands of those who view with disdain the Indo-Islamic synthesis that was forged over centuries of interaction amongst Hindus, Muslims, and even Sikhs. If Pakistan has over the last 25 years been increasingly convulsed by violence, this is scarcely only on account of the turmoil in neighboring Afghanistan since the Soviet invasion of 1979, the rise of the Taliban, the advent of global jihad, or what Kipling poignantly termed 'the great game'; it also has much to do with Pakistan's disowned Indic self, and with the attempt to repudiate Pakistan's moorings in the dense cultural substratum of Indic civilization. It may even be that just as the turn to 'Islamization' is perhaps best understood as an attempt by Pakistani elites to have common people embrace an allegedly more authentic version of Islam, one

5 The quote is from Zia's first address as Martial Law Administrator and appears in nearly every work on the history of modern Pakistan.

${ }^{6}$ In the heyday of Pakistani cinema, from the mid-1960s to the mid-1970s, there were well over 2000 cinema halls in Pakistan; by 2005, according to Rizwan, the entire country had just 300 cinema screens. However, the fall in film production was, if anything, even more precipitous. In 1979, nearly 100 feature films were produced in Pakistan; by 2001, the number had fallen to two. 
less contaminated by the close proximity to Hinduism, so Hindu nationalism is also shaped by the attempt to Sanskritize Hindu traditions.

Let us allow, then, the argument that scholars and commentators of secular, liberal, and left disposition insist on, namely that popular Indian cinema began to take a different and alarming turn around the late 1980s in its open hostility towards Pakistan and in its open expression of the idea that the country was becoming increasingly vulnerable to the threat from terrorists, almost always envisioned as Pakistani Muslims often working in collaboration with Muslim informants from India. Often these threats to India were viewed as emanating not from non-state actors but from functionaries of the state of Pakistan who were driven by radical ideologies, a palpable hatred for India, and an extraordinarily cunning ability to lure Indian Muslims into the den of terrorist activity. ${ }^{7}$ I have thus far suggested that a number of factors appear to have converged in the 1980s to lend this narrative credence. What is called the 'Nehruvian consensus,' which upheld the idea of secularism as a core value of the Republic, had begun to crack at the seams by the 1970s. The film Indian industry had long been associated with a stellar group of Muslim directors, lyricists, music composers, screenwriters, and actors, whose own conviction in a secularism that was derived from their faith rather than from the worldview of the Enlightenment had shaped the outlook of Indian cinema. Their presence by the 1970s had greatly diminished; though a new crop of Muslim actors, in particular, now rules the roost, ${ }^{8}$ the changing language of popular films shows how far Indian cinema has gone towards embracing the continuum of Hindi,

7 The Hindi feature film, Sarfarosh (1999), which features Aamir Khan in the role of an Indian policeman who is determined to prevent arms trafficking and cross-border terrorism, is wonderfully illustrative of many of these trends. The famous actor, Naseeruddin Shah, plays the role of Gulfam Hassan, a ghazal singer who, greatly embittered by the partition of India, laments the fate of his fellow Muslims and becomes an informant for Pakistani intelligence services. The word sarfarosh means 'fervor', passionate excitement. It is not an accident that the film was released in April 1999, at a time of greatly heightened tensions between the two countries, and that just three months later a conflict between India and Pakistan broke out in Kargil.

${ }^{8}$ I refer, of course, to the three Khans, not related to each other, who have carved up much of the space for Hindi commercial cinema among themselves. Salman Khan appeals largely to the working class and to the urban proletariat; Shah Rukh Khan's films speak mainly to the middle class, while Aamir Khan's constituency, however widespread it may be, has the characteristic also of drawing from the upper middle class and the relatively well-educated. What is more germane is that none of these actors can be described as flaunting their religion; they do not appear to the public as religiously-marked individuals. It is noteworthy that both Shah Rukh Khan and Aamir Khan are married to Hindu women; Salman has dated several Hindu women and remains, in film society parlance and middle-class gossip, one of India's most "eligible bachelors." Shah Rukh is the nephew of the director Nasir Hussain, in whose film Yaadon ki Baarat he played one of the three brothers in childhood. 
Hindu, and Hindustan (Trivedi 51-86). On the political scene, the Hindu right-wing came to have representation in Parliament, and its strength on India's streets may be gauged by the fact that the Babri Masjid, a sixteenth-century mosque allegedly built on the site of what was once a Hindu temple constructed to honor the birth of the Hindu deity and king Lord Rama, was destroyed by Hindu nationalists in December 1992 even though it had been placed under state construction (Lal 141185); in Kashmir, meanwhile, a number of secessionist groups, some of them advocating armed resistance to the state, had gained prominence. But even this is a narrative in skeletal form: to understand what might have moved the popular Hindi film into new terrains, one might think of such developments as the entry of India and weeks later of Pakistan into the nuclear club in 1998. I have also suggested, however, that the Indo-Islamic socio-cultural synthesis was, in various ways, under assault in both India and Pakistan, and that the gravitational turn towards more rigid, puritanical, and less accommodating forms of Islam in Pakistan cannot be ignored in our attempts to understand the shifting contours of opinion towards Islam and Pakistan, especially among the Indian middle classes. It is these middle classes that have also gained the most from the neo-liberalization policies which became ascendant around 1990.

It is safe to aver that a consensus has emerged in the scholarly community and among public commentators alike that strands of commercial Indian cinema are now heavily compromised by their overt nationalism and even that much of this cinema tacitly works as a handmaiden to Hindu nationalism or what in India is called Hindutva (literally, 'the essence of Hinduism'). One recent scholarly writing embodies this view in its most transparent form, as must be evident from the very title of the article, "Constructing the Nation's Enemy: Hindutva, popular culture and the Muslim 'other' in Bollywood cinema." Its author argues that "Bollywood cinema has exhibited an overt bias towards producing films that capitulate to this radical nationalist discourse professed by the Hindutva ideologues." Though the author claims to engage in "discourse analysis," he effectively summarizes briefly the plots of a number of films revolving around Muslim characters, before moving expeditiously to his conclusion that with the "Hindu majoritarian setting" as its background, "Bollywood cinema has actively engaged in the politics of nationalism engendered by the right-wing neo-fundamentalist Hindutva movement" (Kumar 458). Writing a decade earlier, the political analyst Saibal Chatterjee noted that in the several decades of its existence before around 2000, Hindi cinema had produced no more than four war films, but that it had since churned out several films that dealt, "in one way or another, with the perfidies of Pakistan while singing paeans to the courage and commitment of India's brave young soldiers." Chatterjee deplored the fact that "an influential section of the film industry has willingly accepted the onus of furthering the cause that is central to the perpetuation of the might of the rightwing — kindling and sustaining the fire of patriotism in the hearts of the masses." Chatterjee contends that censorship codes forbid the mention of the enemy's name until the 1990s, but that the lifting of this restriction means that now "there is no stopping the you-have-to-hate-Pakistan-if-you-love-India juggernaut" (2003). Supposing it were true that India’s strict Film Board censorship 
codes prevented the mention of Pakistan, ${ }^{9}$ what is equally striking, and calculated to generate some unease, is Chatterjee's easy endorsement of censorship and the unreflective assumption that censorship can play a productive part in facilitating relations between the two nations.

In marshalling evidence of the jingoistic turn in commercial Indian cinema and its attraction to the Hindutva worldview, scholars have made the question turn largely upon representation. Just how is the Muslim depicted in these films, they ask, and what are the various modes in which the Muslim is othered? A few examples will suffice before we turn to a set of more critical questions about the possibility of reading what appear to be overtly nationalist films in different registers. In seeking to ask how "Hindi cinema since the 1990s has pictured minority Muslims pejoratively, mainly to validate the hegemonic designs embedded in Hindutva majoritarianism," Kumar argues that the films rehearse the cliché about "the inherently arrogant Muslim and the supposedly tolerant Hindu." Kumar obviously recognizes that representations of Muslims are not monolithic, but, quite reasonably, he does not allow himself to be distracted by the trope of the 'good Muslim' - most often an older Muslim male who is a redemptive figure of old-world humanity, who treats every younger woman as his daughter, is mindful of the honor of women, and acts on principle rather than from self-interest ${ }^{10}$ - into thinking that the Hindi film is catholic in its attitudes towards Muslims. The good Muslims of the Hindi film are generally frail, without material influence, powerless in the best of circumstances —in a few words, as T.S. Eliot said of the English romantic poet John Keats, much

${ }^{9}$ I have found nothing in the manuals or guides of the Central Board of Film Censors as such that forbids the explicit mention of Pakistan in commercial Indian films. Nevertheless, Chatterjee's point is not without merit, even if he is not fully cognizant of the implications of his own argument. References to Pakistan were implicit in the film Upkar (1967), and the 1973 film Hindustan ki Kasam, directed by Chetan Anand, was unambiguous in its reference to Pakistan, though even here Pakistan is not named. In the interim, the two countries had fought a war which led to the independence of East Pakistan and the creation of the new nation-state of Bangladesh. Just as tellingly, the same director, Chetan Anand, made a film on the 1962 Sino-Indian War where the Chinese are unabashedly shown as villainous and brutal. China could be named unambiguously as the enemy as Pakistan could not. When, if at all, did it become possible to name Pakistan as the unequivocal enemy and when did Pakistan, in mainstream cinema, cease to become the splintered half of India and move towards occupying the space of a country that was henceforth to be identified only with its aggressive militaristic self?

${ }^{10}$ One of the most endearing examples of 'the good Muslim' is Rahim Chacha, the imam of the village Ramgarh where most of the action of the film Sholay (1975) is set. He provides good counsel to the villagers and impresses upon them the necessity to fight injustice; in retaliation, the criminals take his son's life. In Ketan Mehta's Mirch Masala (1987) the good Muslim appears in the form of Abu Mian, a wizened old man who is the watchman at the masala karkhana, a factory where red chilies are ground into powder. The local tax collector (subedar) has set his eyes on Sonbai, a village woman of stunning beauty; when on one occasion he finally succumbs to his lust and makes a grab at her, she spurns him and seeks refuge in the chilli factory. Abu Mian shuts its doors in the face of the subedar's henchmen. He holds the fort, so to speak, and his defense of Sonbai eventually emboldens others; though he is eventually shot dead, the women of the factory throw chilli powder at the subedar's face and blind him. 
like "ineffectual angels." For Kumar, as for many others who believe themselves to be deeply committed to the values of a liberal, secular India, the portrayal of the Muslim as the repository of feudal and anti-modern values is offensive. The film Pinjar (Cage 2003), whose plot turns around a Hindu woman who is forcibly married to a Muslim but then accepts him even when, in the midst of the turmoil of Partition, the Hindu man to whom she was first betrothed expresses his willingness to take her back, is characterized by Kumar as engaging "the audience in a dialogical discourse between barbaric Muslims and harmless innocent Hindus." Leaving aside the question of whether Kumar's interpretation doesn't reinforce the very communal outlook that he disdains, it must be asked whether he doesn't too readily accept that the popular Hindi cinema is captive to the idea that 'all Muslims may not be terrorists but all terrorists are Muslims'. Popular cinema is vitiated by "the recurring image of the terrorist as Muslim." (Kumar 464-465).

Sunera Thobani turns her attention to several popular films - Dev (2004, directed by Govind Nihalani); Nandita Das's Firaaq (2008); Rahul Dholakia's Parzania (2007); and the little-known Road to Sangam (2009, directed by Amit Rai) - that reference the pogrom against Muslims in Gujarat in 2002. The man who was then Gujarat's Chief Minister, Narendra Modi, today presides over the destiny of India in his capacity as Prime Minister; sixteen years after the killings which left 2000 Muslims dead and 200,000 homeless, scarcely anyone has been convicted of the crimes perpetrated largely against members of one religious community. Thobani comes to much the same conclusions as Kumar regarding the depiction of "intransigent Muslims," except that her analysis offers greater nuance. She argues that "collective violence is overwhelmingly portrayed in the four films as either sparked by, in response to, or escalated by Muslim behavior, when not actually instigated by Muslims themselves." Indian Muslims are shown cheering for Pakistan as they listen to the commentary of a cricket match in Parzania, and this act of perfidious betrayal of the nation instigates the Hindus to violence; in Dev, the eponymous hero, who acts as a senior police officer, finds himself permitting a demonstration by Muslims who, notwithstanding the promise by their leaders that their protests will be peaceful, turn violent and thus force a police firing. Colonial writers invented the trope of the 'fanatical Muslim' who is always excitable, prone to wild anger, and easily led astray (Pasamsee 2005); and in these films this figure, who spurs his brethren to a vigorous defense of the community and the extirpation of the infidel, finds a new lease of life. Thobani admits that even Hindus are often cast as hate-mongers, filled with irrational animosity for the Muslim; but there is a difference, for "religiously inspired hatred" is "intrinsic to Muslim communities but only to extremist Hindus." (Thobani 493).

Other, perhaps more sophisticated or nuanced, readings of the politics of representation of Muslims and the Pakistani 'other' may yet be possible, and I shall now turn to these in an attempt to probe the central problematic of this paper. The question is whether what is apparently a nationalist cinema in both Pakistan and India is read by the supposedly unlettered masses of South Asia in multiple registers, many of which are, in fact, at cross-purposes with what appears to be full-blown nationalism, and whether popular cinema may not be one of the more arresting ways 
of bridging the 'border' between India and Pakistan. I shall, for various reasons, not least of them being the fact that popular Pakistani cinema is generally little accessible, confine my remarks to popular Indian cinema, though if the supposition that the Indic worldview has not yet been entirely obliterated from Pakistan holds true, then much the same arguments can be advanced for the cinema on the other side of the border. What do we know, for example, of modes of spectatorship on both sides of the border? Is it possible that what appears as jingoism to the secular critic or a reasonable spectator is viewed by Indians who are not assimilated to the values of urban elites as Puranic or mythic lore? The question cannot be reduced only to rituals or protocols of spectatorship, though such a consideration is far from being unimportant, and I shall summon two examples of the possibilities inherent in such a mode of analysis. The "mythological" as an Indian film form is sui generis to popular Hindi cinema, and the 1975 low-budget film, Jai Santoshi Maa, became wildly successful in a year when it faced competition from two of the most iconic works of mainstream cinema, Deewaar (The Wall) and Sholay (Embers). Santoshi Maa was, until the release of the film, a low-brow, little-known goddess with a small following in north India; however, the film generated a cult of the goddess, especially among women who saw in the story an enactment of the female life cycle that might lead to a life of spiritual equipoise and material contentment. The plot of the film is not germane to my argument, but what is much more to the point is the evidence furnished by many film-goers, who have reliably reported that many viewers would take off their shoes before entering the cinema hall. As those with even a sprinkling of knowledge of Hindu religious practices know, worshippers take off their shoes before entering a Hindu temple: here the very space of the cinema hall was sacralized and transformed into a temple, and the very screen becomes the sanctum sanctorum.

The "war film" Border (1997) furnishes my second example. Border is supposed to be based on the 'history' of a specific battle during the 1971 India-Pakistan war in which a regiment of 120 Indian infantrymen successfully defended a border post over a long night of battle against a Pakistani tank regiment with 600 soldiers. In such so-called war films - "so-called" because the notion of distinct genres can be applied only with much reserve if at all to popular Indian cinema, since nearly every film, whether it is a romantic comedy, a horror film, a war film, a thriller, or a social drama, is to some extent an all-purpose carnival - it is important to have one or two loveable Muslim characters among the heroes so that one might be able to distinguish Pakistan from Muslims, akin to the manner in which every liberal in the West, beginning with the supposed leader of the free world, the President of the United States, painfully struggles to distinguish between Islam and those Muslim terrorists who have given their religion a bad name. Border's storyline, as I have written elsewhere, appears to be extraordinarily apposite for such representations, but the film entirely dispensed with such conventions. Its heroes are over the top, not only patriotic and dedicated, but aggressively manly and capable of the supreme sacrifice. The villains, Pakistani Muslims, are one-dimensional, with leery looks and a crafty countenance; perfidy and insincerity are written all over their face. There can be no transgression without a border, and ambiguity is only pos- 
sible and desirable when the lines are clearly drawn: notwithstanding the title of the film, Border does not appear on a casual reading to hint at in-between spaces. Nor was Border sensitive to Muslims within India: as is quite common in such films, it makes the point that a fifth column within India exists to give aid and succor to Pakistanis. Nearly every film reviewer and critic panned the film, and the otherwise witty Nikhat Kazmi, then the film reviewer for the Times of India, condemned the film in unambiguous language: "It is no celebration of patriotism, but jingoism all the way" (Kazmi 1997). Border is still understood in journalistic circles as the antiPakistan film that generated an entire wave of war films (Ayaz 2017). However, the critics had no explanation for why the film was a hit with audiences not only in India but in Pakistan as well, and why its songs were also immensely popular across the border. The Pakistani scholar Muhammad Shoaib Pervez must similarly be put to interrogation when he asserts that "the anti-Pakistan dialogues in the film are its hallmark, punctuated with nationalist melodrama to impress the Indian audiences. However, it may be asked, what message is being conveyed to the Pakistani audiences? It reflects the stereotyping of Pakistan as the 'Other." (Pervez 132). If Pakistanis are not keen on self-flagellation, or unless they have an unusual appetite for tolerating insults, one must assume that Border was viewed in a very different spirit than is imagined by many of its learned critics. If, furthermore, as is often argued, diasporic communities are more ebullient in their profession of zeal for the country, it should be no surprise that Pakistani Britishers sought, without success, a halt to the distribution of video copies of the film in Britain on the grounds that the film was painfully humiliating to Pakistan.

The viewer who has been assimilated to liberal values and believes in the fundamental humanity of every person would doubtless have found scenes in Border to lift his or her hopes. Perhaps the most famous of such scenes has an Indian army officer dive into the burning home of an Indian Muslim astride the border which has been shelled by the Pakistani army and, at great peril to his life as the beams of the house fall all around him, retrieve the villager's copy of the Holy Quran. This act of magnanimity elicits a wondrous look and remark from the villager, "Aur woh tanne kaafir kahe hain" ('And they call you a non-believer'). The critics were less than visibly impressed by this scene, viewing it as a feeble attempt on the part of director J.P. Dutta to affirm the secular credentials of the Indian state and of its uniformed men. The scene's authenticity, moreover, seems to be compromised by the melodramatic setting in which the handover of the sacred book is accomplished to the accompaniment of didactic dialogue. When the villager expresses astonishment that a Hindu army officer would go to such lengths to rescue his Quran, Captain Bhairon Singh replies: 'Hindu: To forget oneself and serve others, this is what is Hindu Dharma [religion]. For centuries, this is what a Hindu has been doing."

To the secular critic in India, this is yet another instantiation of the vanity of Hindus, an arrogant expression of the idea of Hindu tolerance. Yet, as I would like to suggest, audiences in both India and Pakistan would have been alert to a different reading, one which belies the widely accepted notion that a jingoistic film such as Border cannot possibly be interpreted in registers which allow one to think both of conflict resolution and shared cultural assumptions across borders. Significantly, 
though the film seeks to establish Captain Bhairon Singh's predisposition towards Hindu beliefs at a number of points, the scene in question is an affirmation of the secular worldview, if by secularism we also mean, as is evidently the case in India, respect for all religions. Captain Bhairon Singh thus derives his secularism from his faith as a Hindu, a point that would have been well understood both among Indian Muslims and in Pakistan. The Holy Quran provides a critical semiology, too: though Hindus are not even 'people of the book', the reverence for the sacred word is shared across religious cultures. Border does not only point to the idea that the religious sensibility and the secular worldview are complementary; it, more transparently, adopts the view that a secularism that is not derived from the practice of religion has, at least in South Asia, no ethical standing.

Let me, in closing, direct my attention very briefly to the "romantic blockbuster," Veer-Zaara (2004), the plot of which revolves around the apparently ill-fated love affair of an Indian air force officer and a Pakistani woman. Fate brings together Veer Pratap Singh (Shah Rukh Khan) an officer in the Indian Air Force, and Zaara Hayat Khan (Preity Zinta), the daughter of a well-established Pakistani politician living in Lahore. Zaara is in India on a short visit to immerse the ashes in the Sutlej river at a Sikh pilgrimage site of a Sikh woman who, by dint of circumstances arising from the Partition, found herself taken in by Zaara's family and over the decades becomes deeply attached to members of the family. An unstated romance develops between Zaara and Veer, but Zaara has already been committed to another man by her family; she returns to Pakistan, and as young women in her situation are wont to do so, frets, agonizes, and pines for her lover. Her female companion places a call to Veer, who, turning in his resignation as an Indian Air Force officer, arrives at Zaara's doorstep to ask for her hand in marriage. Zaara's fiancé, whose honor, reputation, and manliness have now been put at risk by this interloper from India, has Veer framed as a spy with the encouragement of Zaara's father. Veer, who has been compelled to sign a confession stating that he is Rajesh Rathore, an employee of India's spy agency RAW (Research and Analysis Wing), languishes in a Pakistani jail for upwards of twenty years, though the word is put out that he has been killed in a road accident. A young Pakistani lawyer, Saamiya Siddiqui (Rani Mukerji), is drawn to Veer's cause, and takes a pledge to restore his name, his identity, and his country to him. Veer and Zaara are united by dint of a Pakistani court's finding that Veer Pratap Singh was framed, that he consented to sign a false confession only to save the honor of a Pakistani woman, and that his freedom must be restored to him.

Veer Zaara became a landmark film that was generally held in high regard both in India and Pakistan as a work that highlights the social norms and cultural values that are common to both countries and thus had the potential to heal relations between them. Oddly enough, though this subject cannot be unraveled at this juncture, the ban in Pakistan on the official screening of Indian movies which went into effect in the aftermath of the 1965 Indo-Pak war, was still in place and would not be lifted until 2008; however, as was the case with nearly all Indian movies, bootlegged copies of Veer Zaara were widely available and were often screened openly. Many film reviewers in Pakistan embraced the film as it appeared to humanize Pakistanis, furnish Islam with a human face, and suggest that the border is an artifact of history. 
Such a reading, of course, obscures the fact that contingency marks every border. Moreover, once we are past the tiresome cliché that love transcends all borders, it remains to be asked how exactly Veer Zaara effects a departure in its treatment of Pakistan and in its more than tacit assumption that political culture might help in conflict resolution? It has long been argued rather vociferously by activists, artists, and scholars on both sides of the border that whatever the animosity between the two states, the people of Pakistan and India only harbor goodwill towards each other; in other words, it is civil society rather than the state that is invested in the peace process. When Veer submits his resignation and abandons the uniform of an officer of the Indian Air Force, should we only read this as an instance of love triumphing over patriotic militarism? Or does that sartorial gesture signify something much more profound, namely that institutions of the state hinder rather than facilitate the building of bridges between the two countries?

The film's deployment of the legal motif, and the consequent denouement, offers one further opening. Though Pakistan and India both inherited the legal system bequeathed by the British, Pakistan's legal system, certainly in comparison to India, became seriously compromised by the adoption of Sharia courts, the Hudood ordinances, the designation of certain groups of Muslims such as the Ahmadiyyas as apostates, and so on. This reading is, of course, tenable only on the assumption that the legal system of the modern West, based on the principle that all defendants brought before a court are to be treated with equality, with absolute indifference to one's race, gender, class, and standing in society, can reasonably be viewed as a model which might be rightly emulated. In either country, there is little awareness of how the law has taken its own course since Partition. Indian viewers would have been surprised at the film's denouement: presiding over a case brought by the lawyer Saamia Siddiqui to secure Veer's release, the court is moved, after the assessment of the evidence and Zaara's own testimony, to order his release. That a large portrait of Mohammed Ali Jinnah, the founder of Pakistan, hangs behind the sitting judge is not merely a matter of protocol. Despite the fact that Pakistan was created explicitly as a state that would shelter the sub-continent's Muslims, Jinnah himself was resolutely wedded to the secular notion - if again we can countenance the idea that secularism must always permit rather than inhibit religious practice, not only in the privacy of one's home but in public. However, Veer Zaara is not without ambiguity on the question of whether the legal framework of the modern nation-state can be enabling in the quest for conflict resolution. The film subtly makes the point that the lawyer Saamiya represents Veer on behalf of the Human Rights Commission of Pakistan - and herein lies the suggestion that transnational organizations, international conventions, and allegedly universal protocols of justice today intrude, often to the advantage of those without a voice, upon the autonomy of the nations-state.

The few instances that I have summoned of popular Hindi cinema's engagement with the analytic and problematic of the border between India and Pakistan nevertheless permit me to offer a few concluding thoughts. Let me propose an odd and imperfect analogy: It is the inescapable nature of water to be free; it will seep through the tiniest crack, and tiny rivulets diverge from the main body and chart 
their own journey. The engineer confronted with a body of water is moved only by one instinct, namely the desire to dam it, contain it, or otherwise find ways to render it efficient in the service of human beings. The realists who have dominated our imagination only construe the border as a problem, as something that must be monitored, regulated, patrolled, and maintained in its status quo. However, the physical border - enforced through rituals, an armed presence on either side, and such contrivances of modernity as the passport - between the states of India and Pakistan is the least of the problems. Many other films besides those which I have mentioned here seem riveted around the border or what is more menacingly called the Line of Control that divides India from Pakistan, yet the central questions they tacitly probe are much more far-reaching in their implications. Something in popular Hindi cinema hints at a more profound notion, one that we shall have to continue to reflect upon as we ponder the border between India and Pakistan, the Hindu and the Muslim, the self and the other. There is something of the Hindu in every South Asian Muslim; there is also something of the Muslim in every Hindu. That recognition allows us to both retain and subvert the border at once.

Reviews sent to author: 1 December 2017 Revised paper accepted for publication: 24 March 2018 


\section{REFERENCES}

Altaf, Waseem. "Filmistan: Here and There," Let Us Build Pakistan, 19 April 2013, https://lubpak. com/archives/258783. Accessed 6 February 2018.

Ayaz, Shaikh. "Border at 20: The JP Dutta war epic and how it launched a wave of war films," Indian Express, 13 June 2017, http://indianexpress.com/article/entertainment/bollywood/ border-at-20-the-jp-dutta-war-epic-and-how-it-launched-a-wave-of-war-films-4702235/. Accessed 7 February 2018

Chatterjee, Saibal. “War Films Are Right Up the Parivar's Street," Hindustan Times, 25 November 2003. http://www.countercurrents.org/comm-chatterjee251103.htm. Accessed 1 March 2018.

GuHA, Ramachandra. India after Gandhi: The History of the World's Largest Democracy. HarperCollins, 2007.

Haqqani, Hussain. Pakistan: Between Mosque and Military. Carnegie Endowment for International Peace, 2005.

Ispahani, Farahnaz. Purifying the Land of the Pure: A History of Pakistan's Religious Minorities. Oxford University Press, 2017.

Kazmi, Nikhat. "It's not a Celebration of Patriotism, but Jingoism all the Way," Times of India, 29 June 1997.

Kumar, Sanjeev. "Constructing the Nation's Enemy: Hindutva, popular culture and the Muslim 'other' in Bollywood cinema," Third World Quarterly 34: 3 (2013), pp. 458-69.

LaL, Vinay and Ashis Nandy. "Popular Cinema and the Culture of Indian Politics." Fingerprinting Popular Culture: The Mythic and the Iconic in Indian Cinema, Vinay Lal and Ashis Nandy eds. Oxford University Press, 2006, pp. Xvi-XviII.

LaL, Vinay. “The Murder of a Sufi Qawaal and a Nation-State in Its Death-Throes," 25 June 2016. https://vinaylal.wordpress.com/2016/06/25/the-murder-of-a-sufi-qawwal-and-a-nationsate-in-its-death-throes/. Accessed 6 February 2018.

“Intolerance for 'Hindu Tolerance': Hinduism, Religious Violence in Pre-modern India, and the Fate of a 'Modern' Discourse," in Religion und Gewalt: Konflikte, Rituale, Deutungen (1500-1800), edited by Kaspar von Greyerz and Kim Siebenhuner. Vandenhoeck \& Ruprecht, 2006, pp.51-84.

"The Defiance of Defiance and Liberation for the Victims of History: Ashis Nandy in Conversation with Vinay Lal," in Dissenting Knowledges, Open Futures: The Multiple Selves and Strange Destinations of Ashis Nandy, ed. Vinay Lal. Oxford University Press, 2013.

- Deewaar: The Footpath, the City, and the Angry Young Man. HarperCollins, 2010.

The History of History: Politics and Scholarship in Modern India, Oxford University Press, 2005

Lawrence, Bruce (ed.). Messages to the World: The Statements of Osama bin Laden. Verso, 2005

Padamsee, Alex. Representations of Indian Muslims in British Colonial Discourse. Palgrave Macmillan, 2005.

Paracha, Nadeem F. "Whatever happened to Pakistan's film industry?" Deutsche Welle 29 August 2015. http://www.dw.com/en/whatever-happened-to-pakistans-film-industry/a-18681029. Accessed 29 January 2018. 
Pervez, Muhammad Shoaib. Security Community in South Asia: India-Pakistan. Routledge, 2012.

RIZWan, Mohammed. "Pakistan's suffering cinemas want to lift celluloid curtain," Mail and Guardian, 2 August 2005. https://mg.co.za/article/2005-08-02-pakistans-suffering-cinemas-want-tolift-celluloid-curtain. Accessed 29 January 2018.

Тноваni, Sunera. "Performing Terror, Mediating Religion: Indian Cinema and the Politics of National Belonging," International Journal of Communication 8 (2014), pp. 483-505.

TRIVEDI, Harish. "All Kinds of Hindi: The Evolving Language of Hindi Cinema," in Fingerprinting Popular Culture: The Mythic and the Iconic in Indian Cinema, Vinay Lal and Ashis Nandy eds. Oxford University Press, 2006. 51-86. 
